\title{
Anal Transitional Zone
}

National Cancer Institute

\section{Source}

National Cancer Institute. Anal Transitional Zone. NCI Thesaurus. Code C32072.

The middle segment of the anal canal between the colorectal and squamous zones. 